\title{
Analysis of factors affecting the fuel economy of ice when operating a hydrocarbon fuel activator
}

\author{
Alexander Maksimenko ${ }^{1, *}$ and Natalia Buryanova ${ }^{1}$ \\ ${ }^{1}$ Don State Technical University, 344003, Gagarina sq., 1, Rostov-on-Don, Russia
}

\begin{abstract}
The article examines the issue of the influence of a hydrocarbon fuel activator on the fuel consumption by the internal combustion engine when the activator is installed in the fuel system when the car is running. The analysis of the previously performed work was carried out, hereupon the installation of a hydrocarbon fuel activator was identified as the parameter influencing the fuel consumption of a vehicle. The indicators that require accounting the rate of fuel consumption when the hydrocarbon fuel activator is installed, have been determined.
\end{abstract}

\section{Introduction}

In modern conditions, hydrocarbon fuels and lubricants became a strategic resource, that is why measures related to saving consumption during vehicle operation, have become especially relevant.

On the one hand, when designing cars, manufacturers need to ensure compliance with the environmental requirements which become tougher each year. Current trends in the transfer of all land vehicles to electric traction do not solve the problems that consumers face when operating electric vehicles: the lack of a developed infrastructure for electric refueling, climatic conditions, and the time spent on charging batteries. On the other hand, the constant increase in the cost of hydrocarbon fuel, environmental standards, leads to an increase in the cost of not only the operational cost of cars equipped with an internal combustion engine, but also an increase in the cost of their design and production.

\section{Methodology}

The study was carried out by methods of scientific analysis of the phenomenon under study, namely: the dialectical method of cognition, methods of analysis and synthesis, comparison, deduction and induction, methods of statistical analysis, methods of mathematical statistics, modeling in real conditions, extrapolation, the method of idealization, methodological methods of systematization, generalization, review and

\footnotetext{
*Corresponding author: MANzel@ya.ru
} 
comparison, comparison of the obtained facts, abstraction, the method of comparative analysis and generalization - in the study of practical test results.

The research methodology is based on test methods (programs) were developed in accordance with generally accepted standards for similar tests in Russia at the stage of prototyping. The purpose of the test is to obtain accurate and reliable results from performance tests in the study of engine fuel economy;

\section{Results}

Current accounting for fuel efficiency varies considerably across countries. For example, in the OECD (Organization for Economic Cooperation and Development) member countries, the average fuel consumption in 2005 was set at 8 liters / $100 \mathrm{~km}$ for new passenger cars. In the USA, the average fuel consumption of cars and light trucks is slightly higher than 9 liters / $100 \mathrm{~km}$. In non-OECD countries, there is no clear data on average fuel efficiency. Of course, these numbers are very relative, since they depend on many factors. [1]

A number of international organizations: the Federation Internationale de l'Automobile (FIA), the International Energy Agency (IEA), the International Transport Forum (ITF) and the United Nations Environment Program (UNEP) have launched the global initiative to improve vehicle fuel efficiency "50 550 . Global Initiative to reduce fuel consumption" includes 11 provisions and is aimed at reducing the fuel consumption of cars. It is assumed by 2050 to reduce the consumed fuel in the world by at least $50 \%$ compared to the current level of fuel efficiency. [2]

Abstract Over the past 25 years more than 20 major studies have examined the technological potential to improve the fuel economy of passenger cars and light trucks in the United States. The majority have used technology/cost analysis, a combination of analytical methods from the disciplines of economics and automotive engineering. In this review we describe the key elements of this methodology, discuss critical issues responsible for the often widely divergent estimates produced by different studies, review the history of this methodology's use, and present results from six recent assessments. Whereas early studies tended to confine their scope to the potential of proven technology over a 10 -year time period, more recent studies have focused on advanced technologies, raising questions about how best to include the likelihood of technological change. The review concludes with recommendations for further research [9].

In the Russian Federation, at the design stage by manufacturers, fuel efficiency is calculated on the basis of the "Methodological Recommendations for the Consumption of Fuels and Lubricants" of the Ministry of Transport of the Russian Federation as the total fuel consumption in liters, referred to the distance traveled in kilometers, depends on the operating mode of the vehicle calculated by the formula:

$\mathrm{QH}=0.01 \mathrm{Hs} \mathrm{S}(1+0.01 \times \mathrm{D})$,

where $\mathrm{QH}$ - fuel consumption rate, 1 ;

Hs- basic rate of fuel consumption per $100 \mathrm{~km},(1 / 100 \mathrm{~km})$;

$\mathrm{S}$-vehicle mileage, $\mathrm{km}$;

D - correction factor (total relative increase or decrease) to the norm, $\%$.

The fuel consumption rates published by the Ministry of Transport of the Russian Federation for 2019 are presented in Table 1 by brands of cars participating in the experiment with the main technical characteristics of the engine and transmission, type of fuel and lubricants.

Table 1. Fuel consumption rates of the Ministry of Transport, 2019

\begin{tabular}{|c|c|c|c|}
\hline $\begin{array}{c}\text { Model, make, modification of } \\
\text { the car }\end{array}$ & $\begin{array}{c}\text { Engine power, } \\
\text { h.p. }\end{array}$ & $\begin{array}{c}\text { Engine } \\
\text { capacity, }\end{array}$ & $\begin{array}{c}\text { Basic fuel } \\
\text { consumption rate, I / }\end{array}$ \\
\hline
\end{tabular}




\begin{tabular}{|c|c|c|c|}
\hline & & liters & $\mathbf{1 0 0} \mathbf{~ k m}$ \\
\hline Solaris 1.6 & 123 & $4 \mathrm{~A}$ & 8.1 \\
\hline Rio 1.6 & 123 & $5 \mathrm{M}$ & 7.4 \\
\hline Forester 2.0 & 158 & $5 \mathrm{M}$ & 10.3 \\
\hline Grand Vitara 2 7 2WD & 185 & $5 \mathrm{~A}$ & 13.3 \\
\hline Toyota Auris 1 6 (E15J, E15UT) & 124 & $5 \mathrm{~A}$ & 8.5 \\
\hline
\end{tabular}

To obtain more accurate values, a number of experiments were carried out to study the characteristics of vehicles equipped with a fuel activator in Rostov-on-Don.

Based on previous studies, it was found that fuel economy is obtained when the fuel activator is installed in the fuel system. The results are presented in Table 2.

The tests were carried out on passenger cars of different brands, under different climatic conditions, different settings of the hydrocarbon fuel activator, different brands of fuel, outside city traffic. The following was unchanged: the route was $17.7 \mathrm{~km}$, the average speed was $76 \mathrm{~km} / \mathrm{h}$, the time to complete the route was $14-15$ minutes.

Table 2. Influence of installing a hydrocarbon fuel activator installed inside the vehicle fuel system

\begin{tabular}{|c|c|c|c|}
\hline \multirow[b]{2}{*}{ Test* } & \multicolumn{2}{|c|}{ Average fuel consumption I / $100 \mathrm{~km}$. } & \multirow{2}{*}{$\begin{array}{c}\text { Difference of } \\
\text { indicators, in \% }\end{array}$} \\
\hline & $\begin{array}{l}\text { Consumption without } \\
\text { activator of } \\
\text { hydrocarbon fuel }\end{array}$ & $\begin{array}{l}\text { Consumption with } \\
\text { the installed } \\
\text { hydrocarbon fuel } \\
\text { activator }\end{array}$ & \\
\hline \multicolumn{4}{|c|}{ Car 2.7 l. (185 h.p.) } \\
\hline Test 1 (RON-80) & 9.1 & 8.4 & 7.69 \\
\hline Test 2 (RON-80) & 9.2 & 8.6 & 6.52 \\
\hline Test 3 (RON-80) & 9.1 & 8.5 & 6.59 \\
\hline Test 4 (RON-92) & 8.5 & 8.1 & 4.71 \\
\hline Test 5 (RON-92) & 8.4 & 8.1 & 3.57 \\
\hline Test 6 (RON-95) & 8.3 & 8.0 & 3.61 \\
\hline Test 7 (RON-95) & 8.3 & 7.9 & 4.82 \\
\hline & & Mean & 5.36 \\
\hline \multicolumn{4}{|c|}{ Car 2.0 1. (158 h.p.) } \\
\hline Test 1 (RON-92) & 9.8 & 9.1 & 7.14 \\
\hline Test 2 (RON-92) & 9.0 & 8.4 & 6.67 \\
\hline Test 3 (RON-92) & 9.6 & 7.6 & 20.83 \\
\hline Test 4 (RON-95) & 8.3 & 7.8 & 6.02 \\
\hline Test 5 (RON-95) & 8.1 & 7.4 & 8.64 \\
\hline & & Mean & 9.86 \\
\hline \multicolumn{4}{|c|}{1.6 liter car. (124 h.p.) } \\
\hline Test 1 (RON-92) & 8.4 & 7.3 & 13.10 \\
\hline Test 2 (RON-95) & 7.1 & 5.2 & 26.76 \\
\hline & & Mean & 19.93 \\
\hline \multicolumn{4}{|c|}{1.6 liter car. (123 h.p.) } \\
\hline Test 1 (RON-95) & 7.6 & 6,7 & 11.84 \\
\hline Test 2 (RON-95) & 7,7 & 6.8 & 11.69 \\
\hline & & Mean & 11.77 \\
\hline \multicolumn{4}{|c|}{ Car 2.5 1. (145 h.p.) } \\
\hline Test 1 (Diesel) & 12.6 & 10.3 & 18.25 \\
\hline & & Total on average & 13.03 \\
\hline
\end{tabular}


Based on the data presented in Table 1, it was found that vehicles equipped with the fuel activator provide an average fuel economy of $3.57-13.03 \%$. There is a relation between engine capacity and fuel consumption. This device provides the best performance for reducing fuel consumption on small engines, which is clearly shown in Figure 1.

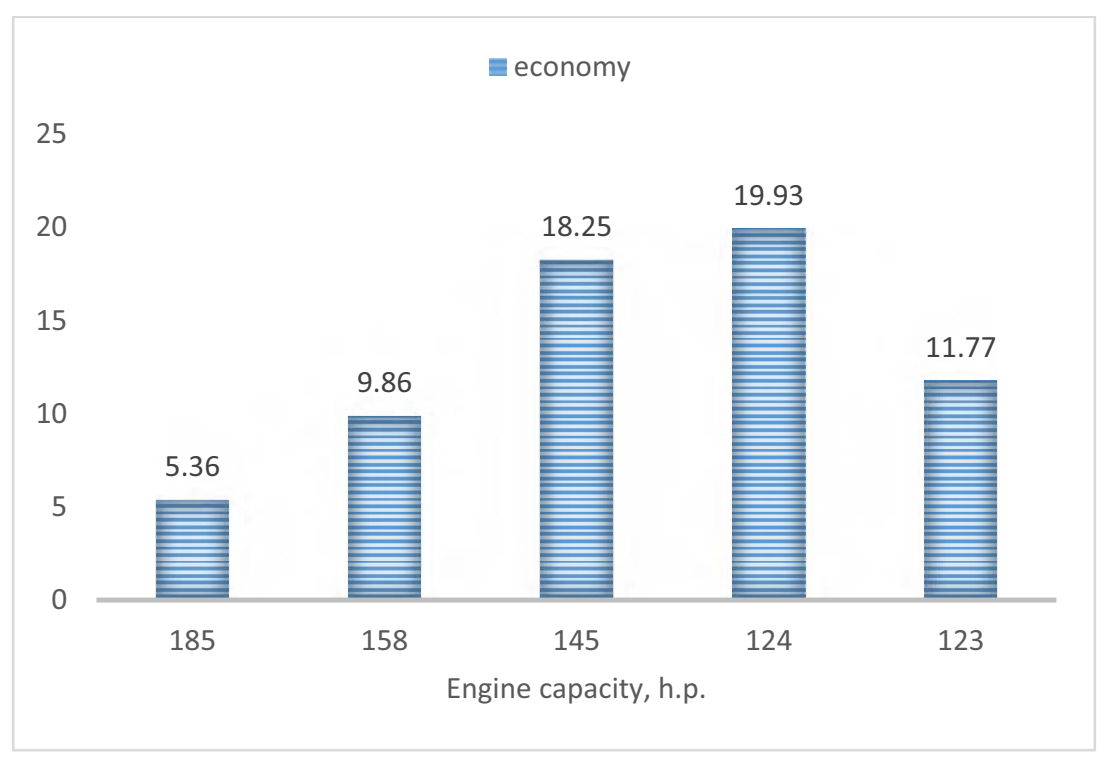

Fig. 1. Engine capacity and fuel economy

It can also be argued that the efficiency of the activator depends not only on the volume of the engine, but also on its quality characteristics.

To confirm the results of the experiment, a series of tests for emissions of harmful substances was also carried out on one of the test vehicles. The measurement number from 1 to 5 tests corresponds to an interval of 10 seconds, the test results are shown in Table 3. The measurements were carried out according to the following parameters: $\mathrm{CO} 2, \%, \mathrm{CO}$, $\mathrm{mg}, \mathrm{SO} 2, \mathrm{mg}, \mathrm{NO} 2, \mathrm{mg}$ before and after installation of the activator.

The first series of tests of the fuel activator consisted in measuring the content of harmful compounds in the exhaust gases of the tested car with a gas analyzer COMETA-M № 30164 in two engine operating modes of $2000 \mathrm{rpm}$ and $3000 \mathrm{rpm}$ at an ambient temperature of $26^{\circ} \mathrm{C}$.

Table 3. Test results of a car engine with a gas analyzer COMETA-M № 30164 in two engine operating modes $2000 \mathrm{rpm}$ and $3000 \mathrm{rpm}$

\begin{tabular}{|c|c|c|c|c|c|}
\hline \multicolumn{7}{|c|}{ First test cycle engine speed 3000 rpm } \\
\hline \multicolumn{2}{|c|}{ Measurement } & CO2,\% & CO, $\mathbf{~ m g}$ & SO2, $\mathbf{~ m}$ & NO2, $\mathbf{~ m g}$ \\
\hline \multirow{2}{*}{1} & before & 2.67 & 373 & 21.8 & 1.6 \\
\cline { 2 - 6 } & after & 8.53 & 0 & 12.1 & 1.0 \\
\hline \multirow{2}{*}{2} & before & 2.92 & 373 & 21.8 & 1.7 \\
\cline { 2 - 6 } & after & 8.53 & 0 & 11.2 & 0.7 \\
\hline \multirow{2}{*}{3} & before & 8.53 & 373 & 21.8 & 1.7 \\
\cline { 2 - 6 } & after & 8.53 & 0 & 7.0 & 0.6 \\
\hline \multirow{2}{*}{4} & before & 8.53 & 373 & 21.8 & 1.8 \\
\cline { 2 - 6 } & after & 8.53 & 0 & 6.5 & 0.5 \\
\hline \multirow{2}{*}{5} & before & 8.53 & 373 & 21.8 & 1.8 \\
\cline { 2 - 6 } & after & 8.53 & 0 & 7.2 & 0.3 \\
\hline
\end{tabular}




\begin{tabular}{|c|c|c|c|c|c|}
\hline \multirow[t]{2}{*}{ The average } & before & 6.25 & 373 & 21.8 & 1.72 \\
\hline & after & 8.53 & 0 & 8.8 & 0.62 \\
\hline \multicolumn{6}{|c|}{ Second test cycle engine speed $2000 \mathrm{rpm}$} \\
\hline \multicolumn{2}{|c|}{ Measurement } & $\mathrm{CO} 2, \%$ & $\mathrm{CO}, \mathrm{mg}$ & $\mathrm{SO} 2, \mathrm{mg}$ & $\mathrm{NO} 2, \mathrm{mg}$ \\
\hline \multirow[t]{2}{*}{1} & before & 2.32 & 373 & 21.9 & 1,2 \\
\hline & after & 1.19 & 373 & 7.2 & 0.8 \\
\hline \multirow[t]{2}{*}{2} & before & 8.53 & 373 & 21.5 & 0.8 \\
\hline & after & 1.81 & 373 & 11.4 & 0.2 \\
\hline \multirow[t]{2}{*}{3} & before & 8.53 & 373 & 21.9 & 0.7 \\
\hline & after & 8.53 & 373 & 21.9 & 0,4 \\
\hline \multirow[t]{2}{*}{4} & before & 8.53 & 373 & 21.9 & 0.3 \\
\hline & after & 8.53 & 373 & 21.9 & 0,4 \\
\hline \multirow[t]{2}{*}{5} & before & 8.53 & 373 & 21.9 & 0.3 \\
\hline & after & 8.53 & 373 & 21.9 & 0.3 \\
\hline \multirow[t]{2}{*}{ The average } & before & 7.288 & 373 & 21.82 & 0.66 \\
\hline & after & 7,062 & 373 & 16.86 & 0.42 \\
\hline
\end{tabular}

The second series of tests of the fuel activator consisted in measuring the content of harmful compounds in the exhaust gases of the tested car with a gas analyzer Drager X-am 5000 No. 8318704 in two engine operating modes $2000 \mathrm{rpm}$ and $3000 \mathrm{rpm}$ at an ambient temperature of $26^{\circ} \mathrm{C}$. Measurement numbers from 1 to 5 tests correspond to an interval of 10 seconds, the test results are shown in Table 4.

Table 4. Test results of a car engine with a Drager X-am 5000 gas analyzer No. 8318704 in two engine operating modes $2000 \mathrm{rpm}$ and $3000 \mathrm{rpm}$

\begin{tabular}{|c|c|c|c|c|c|c|c|c|c|c|}
\hline \multicolumn{11}{|c|}{ First test cycle engine speed $3000 \mathrm{rpm}$} \\
\hline \multirow{2}{*}{ Measurement } & \multicolumn{2}{|c|}{1} & \multicolumn{2}{|c|}{2} & \multicolumn{2}{|c|}{3} & \multicolumn{2}{|c|}{4} & \multicolumn{2}{|c|}{5} \\
\hline & before & after & before & after & before & after & before & after & before & after \\
\hline $\mathrm{CO}, \mathrm{ppm}$ & 1490 & 16 & 1980 & 18 & 1950 & 20 & 1980 & 22 & 1500 & 20 \\
\hline $\mathrm{CO} 2, \%$ & 1,2 & -0.6 & 1.1 & -0.6 & 1.0 & 0 & 1,2 & 0 & 1,2 & 0 \\
\hline $\mathrm{NO} 2, \mathrm{ppm}$ & 1.3 & -1.4 & 1.2 & -3 & $\begin{array}{l}\text { top. } \\
\text { prev. }\end{array}$ & -2 & $\begin{array}{l}\text { top. } \\
\text { prev. }\end{array}$ & -2.5 & $\begin{array}{l}\text { top. } \\
\text { prev. }\end{array}$ & -2.5 \\
\hline
\end{tabular}

Second test cycle engine speed $2000 \mathrm{rpm}$

\begin{tabular}{|c|c|c|c|c|c|c|c|c|c|c|}
\hline \multirow{2}{*}{ Measurement } & \multicolumn{2}{|c|}{1} & \multicolumn{2}{|c|}{2} & \multicolumn{2}{|c|}{3} & \multicolumn{2}{c|}{4} & \multicolumn{2}{c|}{5} \\
\cline { 2 - 12 } & before & after & before & after & before & after & before & after & before & after \\
\hline $\mathrm{CO}, \mathrm{ppm}$ & 592 & 14 & 654 & 18 & 706 & 20 & 645 & 24 & 620 & thirty \\
\hline $\mathrm{CO} 2, \%$ & 4.1 & 2.1 & 4.4 & 1.9 & 2.1 & 1.8 & 1.7 & 1.6 & 2.3 & 1.3 \\
\hline $\mathrm{NO} 2, \mathrm{ppm}$ & $\begin{array}{c}\text { top. } \\
\text { prev. }\end{array}$ & 1.3 & $\begin{array}{c}\text { top. } \\
\text { prev. }\end{array}$ & 1.5 & $\begin{array}{c}\text { top. } \\
\text { prev. }\end{array}$ & $\begin{array}{c}\text { top. } \\
\text { prev. }\end{array}$ & $\begin{array}{c}\text { top. } \\
\text { prev. }\end{array}$ & top. prev. & $\begin{array}{c}\text { top. } \\
\text { prev. }\end{array}$ & $\begin{array}{c}\text { top. } \\
\text { prev. }\end{array}$ \\
\hline
\end{tabular}

The third series of tests of the fuel activator consisted in measuring the content of harmful compounds in the exhaust gases of the tested car with a gas analyzer COMETA-M № 30164 in two engine operating modes $2000 \mathrm{rpm}$ and $3000 \mathrm{rpm}$ at an ambient temperature of $23^{\circ} \mathrm{C}$. Measurement number from 1 to 15 tests corresponds to an interval of 10 seconds, the test results are shown in table 5.

Table 5. Test results of a car engine with a gas analyzer COMETA-M № 30164 in two engine 
operating modes $2000 \mathrm{rpm}$ and $3000 \mathrm{rpm}$

\begin{tabular}{|c|c|c|c|c|c|c|c|c|c|c|}
\hline \multicolumn{11}{|c|}{ First test cycle engine speed 3000 rpm } \\
\hline \multirow{2}{*}{ Measurement } & \multicolumn{2}{|c|}{1} & \multicolumn{2}{|c|}{2} & \multicolumn{2}{|c|}{3} & \multicolumn{2}{|c|}{4} & \multicolumn{2}{|c|}{5} \\
\hline & before & after & before & after & before & after & before & after & before & after \\
\hline $\mathrm{CO} 2, \%$ & 1.48 & 0.36 & 5.48 & 1.47 & 8.53 & 5.13 & 8.53 & 8.53 & 8.53 & 8.53 \\
\hline $\mathrm{CO}, \mathrm{mg}$ & 24 & 0 & 105 & 0 & 74 & 0 & 87 & 0 & 64 & 0 \\
\hline $\mathrm{SO} 2, \mathrm{mg}$ & 10.9 & 12.2 & 9.1 & 12.0 & 7.9 & 9.1 & 6.9 & 7,7 & 5.5 & 6.9 \\
\hline $\mathrm{NO} 2, \mathrm{mg}$ & 0,4 & 0.7 & 0.7 & 0.9 & 0.8 & 1.1 & 0.5 & 1.0 & 0,4 & 0.7 \\
\hline \multirow{2}{*}{ Measurement } & \multicolumn{2}{|c|}{6} & \multicolumn{2}{|c|}{7} & \multicolumn{2}{|c|}{8} & \multicolumn{2}{|c|}{9} & \multicolumn{2}{|c|}{10} \\
\hline & before & after & before & after & before & after & before & after & before & after \\
\hline $\mathrm{CO} 2, \%$ & 8.53 & 8.53 & 8.53 & 8.53 & 8.53 & 8.53 & 8.53 & 8.53 & 8.53 & 8.53 \\
\hline $\mathrm{CO}, \mathrm{mg}$ & 47 & 0 & 0 & 0 & 0 & 0 & 0 & 0 & 0 & 0 \\
\hline $\mathrm{SO} 2, \mathrm{mg}$ & 4.7 & 6.1 & 9.4 & 5.9 & 10.1 & 5.1 & 9.4 & 4.1 & 8.4 & 4,3 \\
\hline $\mathrm{NO} 2, \mathrm{mg}$ & 0.3 & 0.6 & 0.2 & 0.5 & 0.9 & 0,4 & 1.1 & 0.3 & 1.0 & 0.3 \\
\hline \multirow{2}{*}{ Measurement } & \multicolumn{2}{|c|}{11} & \multicolumn{2}{|l|}{12} & \multicolumn{2}{|c|}{13} & \multicolumn{2}{|c|}{14} & \multicolumn{2}{|c|}{15} \\
\hline & before & after & before & after & before & after & before & after & before & after \\
\hline $\mathrm{CO} 2, \%$ & 8.95 & 8.53 & 8.53 & 8.53 & 8.53 & 8.53 & 8.53 & 8.53 & 8.53 & 8.53 \\
\hline $\mathrm{CO}, \mathrm{mg}$ & 0 & 0 & 0 & 0 & 0 & 0 & 0 & 0 & 0 & 0 \\
\hline $\mathrm{SO} 2, \mathrm{mg}$ & 7.0 & 4.0 & 6.0 & 3.9 & 5.5 & 2.9 & 4.9 & 2.6 & 2.9 & 3.0 \\
\hline $\mathrm{NO} 2, \mathrm{mg}$ & 0.9 & 0.3 & 0.8 & 0.3 & 0.7 & 0.3 & 0.6 & 0.2 & 0,4 & 0.2 \\
\hline \multicolumn{11}{|c|}{ Second test cycle engine speed $2000 \mathrm{rpm}$} \\
\hline \multirow{2}{*}{ Measurement } & \multicolumn{2}{|l|}{1} & \multicolumn{2}{|c|}{\begin{tabular}{|c|c|}
2 & \\
\end{tabular}} & \multicolumn{2}{|c|}{\begin{tabular}{l|l}
3 \\
\end{tabular}} & \multicolumn{2}{|l|}{4} & \multicolumn{2}{|c|}{5} \\
\hline & before & after & before & after & before & after & before & after & before & after \\
\hline $\mathrm{CO} 2, \%$ & 1,2 & 0.41 & 8.53 & 1.56 & 8.53 & 8.53 & 8.53 & 8.53 & 8.53 & 8.53 \\
\hline $\mathrm{CO}, \mathrm{mg}$ & 373 & 0 & 373 & 52 & 373 & 172 & 373 & 373 & 373 & 373 \\
\hline $\mathrm{SO} 2, \mathrm{mg}$ & 21.8 & 8.1 & 21.8 & 10.0 & 21.8 & 21.4 & 21.8 & 21.8 & 21.8 & 21.8 \\
\hline $\mathrm{NO} 2, \mathrm{mg}$ & 0.7 & 0.8 & 0.8 & 0.9 & 0,4 & 0.7 & 0.2 & 0.5 & 0 & 0.1 \\
\hline
\end{tabular}

Suzuki Grand Vitara 2.7 liter without a catalytic converter was used in all three series of tests; the same RON-92 gasoline purchased from the Gazprom filling station network was used as fuel.

The analysis of the calculated average measurement values before and after the installation of the fuel activator for the content of harmful compounds in the exhaust gases of the tested vehicle for two test cycles of $2000 \mathrm{rpm}$ and $3000 \mathrm{rpm}$ is presented in Table 6 .

Table 6. Average values of the test results of a car engine with a gas analyzer COMETA-M № 30164 in two engine operating modes $3000 \mathrm{rpm}$ and $2000 \mathrm{rpm}$

\begin{tabular}{|c|c|c|c|c|c|c|}
\hline \multirow{2}{*}{ Measurement } & \multicolumn{3}{|c|}{ Test cycle 3000 rpm } & \multicolumn{3}{c|}{ Test cycle 2000 rpm } \\
\cline { 2 - 7 } & before & after & difference & before & after & difference \\
\hline $\mathrm{CO} 2, \%$ & 7.88 & 7.29 & -0.07 & 7.06 & 5.51 & -1.49 \\
\hline $\mathrm{CO}, \mathrm{mg}$ & 26.73 & 0.00 & -26.73 & 373 & 194 & -179 \\
\hline $\mathrm{SO} 2, \mathrm{mg}$ & 7.24 & 5.99 & -1.25 & 21.8 & 16.62 & -5.18 \\
\hline $\mathrm{NO} 2, \mathrm{mg}$ & 0.65 & 0.52 & -0.13 & 0.42 & 0.06 & -0.36 \\
\hline
\end{tabular}

In general, the results of the conducted tests of the fuel activator to measure the content of harmful compounds in the exhaust gases made it possible to make the following conclusions.

In the operating mode of the internal combustion engine at $3000 \mathrm{rpm}$, a decrease in the 
$\mathrm{CO}$ indicator to zero is observed, which occurs faster with the use of a fuel activator device. The indicators of $\mathrm{SO} 2$ and $\mathrm{NO} 2$ with the use of a fuel activator decreased, but the parameters of $\mathrm{CO} 2$ did not change.

In the engine operating mode of $2000 \mathrm{rpm}$, a more significant decrease in the average measuring values was also observed at the end of the test cycle with the fuel activator installed. So, according to table 6, the indicator $\mathrm{CO} 2, \%$ decreased (from 7.06 to 5.51), the relative change was $-1.49 \%, \mathrm{CO}, \mathrm{mg}$ decreased (from 373 to 194 ), the absolute change was - $179 \mathrm{mg}$, SO2, mg decreased (from 21, 8 to 16.62), the change was - $5.18 \mathrm{mg}$, and NO2, $\mathrm{mg}$ decreased (from 0.42 to 0.06 ), the change was $-0.36 \mathrm{mg}$.

\section{Conclusions}

Thus, according to the results of two series of conducted tests of the fuel activator, it can be concluded that the installation of a fuel activator in the section of the fuel system of a car leads to significant fuel savings and, as a consequence, a reduction in the average value of harmful emissions of exhaust gases from cars with internal combustion engines, which fully complies with standard foreign researchers such as: Fontaras, G., Rexeis, M., Dilara, P., Hausberger, S., Anagnostopoulos, K., David L. Greene, John DeCicco., Pasaoglu, G., Honselaar, M. and Thiel, C., Tang, B., Wu, X. and Zhang, X. and others [6, 10, 12, 17, 18].

The operation of the device is based on an innovative way of influencing hydrocarbon molecules (gasoline, diesel fuel, methanol, fuel oil, etc.) by electromagnetic oscillations of the resonant frequency. The principle allows obtaining a directed explosion in the combustion chamber of an internal combustion engine, which propagates faster than usually and with greater intensity. This significantly improves the traction characteristics of the combustion engine and significantly reduces harmful emissions into the atmosphere.

\section{References}

1. Prospects and Progress Executive Summary. URL: http://www.globalfueleconomy.org/Documents/Publications/executive-summary.pdf (Last accessed 22.07.2020)

2. H. Mohammed, A. Al-Othman, P. Nancarrow, M. Tawalbeh, M. El Haj Assad, Direct hydrocarbon fuel cells: A promising technology for improving energy efficiency. Energy (2019) https://doi.org/10.1016/j.energy.2019.01.105

3. S. Wang, G. Li, H. Guo, X. Li, X. Pu, H. Ren, D. Wu, Experimental study on vented deflagration of hydrocarbon fuel-air mixtures in a $20-\mathrm{L}$ semi-confined cylindrical vessel with a slight static activation pressure. https://doi.org/10.1016/j.jlp.2020.104091

4. Z. Li, G. Liu, R. Zhang, Heat transfer to supercritical hydrocarbon fuel in horizontal tube: Effects of near-wall pyrolysis at high heat flux. Chemical Engineering Science https://doi.org/10.1016/j.ces. 2020.115994

5. Yu. V. Vorobyov, A. P. Kuzmin, Chemical action of water hammer in the motor fuel activator Vestnik of Tambov State Technical University, 20(1), 95-100 (2014)

6. G. Fontaras, M. Rexeis, P. Dilara, S. Hausberger, K. Anagnostopoulos, The development of a simulation tool for monitoring heavy-duty vehicle $\mathrm{CO} 2$ emissions and fuel consumption in Europe. SAE Paper (24), 0150 (2013)

7. N. A. Kuzmin, G. V. Borisov, A. A. Pikulkin, Influence of the quality of driving a car on the durability of the engine, article in the proceedings of the conference - Safety of vehicles in operation: Collection of materials of the 79th international scientific and 
technical conference. Publisher: Nizhny Novgorod State Technical University. R.E. Alekseeva, 181-183 (Nizhny Novgorod, 2012)

8. A. E. Lomovskikh, Yu. V. Vorobiev, V. V. Tatarinov, A. I. Rastorgueva, Motor fuel activator for improving the performance properties of liquid hydrocarbon fuel Scientific Bulletin of the Voronezh State University of Architecture and Civil Engineering. Materials of the interregional scientific-practical conference "High technologies in ecology", 1, 178-181 (2012)

9. H. Lee, H. Choi, Analysis of vehicle fuel efficiency and survival patterns for the prediction of total energy consumption from ground transportation in Korea. Int.J Automot. Technol, 17, 605-616 (2016) https://doi.org/10.1007/s12239-016-0060-7

10. D. L. Greene, J. DeCicco, Engineering-economic analyses of automotive fuel economy potential in the unitedstates. ORNL/TM-2000/26 U.S. Department of Energy Washington, DC.

11. Publication "Fuel consumption rates of the Ministry of Transport, 2019" industrialmachine.ru/normy-rashoda-topliva-mintransa-rf-god/ (Last accessed 22.07.2020)

12. G. Pasaoglu, M. Honselaar, C. Thiel, Potential vehicle fleet $\mathrm{CO} 2$ reductions and cost implications for various vehicle technology deployment scenarios in Europe. Energy Policy, 40, 404-421 (2012)

13. Economical operation technologies: Fuel activator "Bars". http://www.rostovbars.ru/index.html (Last accessed 22.07.2020)

14. E. N. Khristoforov, N. E. Sakovich, Transport and Environment (Monograph, Bryansk State Agrarian University, 2012)

15. Khudyakov D.A. Problems of fuel economy in the world and their solution // [Electronic resource] - Access mode: $\underline{\text { http://conf.sfu- }}$ kras.ru/sites/mn2012/thesis/s026/s026-018.pdf (Last accessed 22.07.2020)

16. E. V. Tsvetkova, A. V. Tsvetkov, E. V. Sycheva, Improving the environmental performance of automotive fuels by the method of physical activation and magnetic phenomena, Natural and mathematical sciences in the modern world: collection of articles. Art. by mater. XII int. scientific-practical conf. Novosibirsk: SibAK, 11(11) (2013)

17. B. Tang, X. Wu, X. Zhang, Modeling the $\mathrm{CO} 2$ emissions and energy saved from new energy vehicles based on the logistic-curve. Energy Policy, 57, 30-35 (2013)

18. T. Zheng, Y. Jin, Z. Wang, M. Wang, F. Fung, F. Kamakate, H. Gong, Development of fuel consumption test method standards for heavy-duty commercial vehicles in China. SAE Paper (01), 2292 (2011) 